\title{
THE KNOT AS A MIGRANT IN SOUTHERN MANITOBA ${ }^{1}$
}

by Martin K. McNicholl, Zoology Dept., University of Manitoba, Winnipeg

Godfrey (1966) summarizes the status of the Knot (Calidris canutus) in Manitoba, by calling it an uncommon transient in interior Manitoba and a common transient on the west coasts of James and Hudson Bays. Because of its regular occurrence in spring migration along the west coast of Hudson Bay in northeastern Manitoba, the Knot is included on the latest check-list of Manitoba birds (Nero and Hosford, 1967) as a "regular species", that is, "believed to occur every year in some part of the province during one or more of the seasons." As indicated by Godfrey's statements, however, it is considered to be uncommon or rare in the southern part of the province.

I was therefore surprised on May 30,1967 to see a flock of 12 Knots, plus three individual Knots, among a group of shorebirds, including 200 Black-bellied Plover (Squatarola squatarola), 10 American Golden Plover (Pluvialis dominica), 15 Ruddy Turnstone (Arenaria interpres), two Dunlin (Erolia alpestris), and three Sanderling (Crocethia alba), which were feeding on "borrow pits" (mud pits created by construction activity) at the University of Manitoba Field Station at Delta, Manitoba. The following characteristics of the 15 Knots were observed through $8 \times 42$ binoculars: "chunky; larger than turnstones, smaller than Black-bellied Plovers, and closer in size to Golden Plovers; orange-red breast; no ventral spots or streaks; short straight bill, about equal in length with head; in flight, some white on wings and rump, but not extensive". These features agree with the characteristics given for the Knot by Peterson (1947). The birds were again seen later that afternoon by Dr. Roger

${ }^{1}$ Publication No. 9 of the University of Manitoba Field Station, Delta.
M. Evans and the writer, but were not seen subsequently.

Although Godfrey refers to the Knot as uncommon in interior Manitoba, and the A.O.U. committee (1957) says the spring flight passes "rarely through the interior" (p. 193 ), earlier writers are not in agreement as to its status in southern Manitoba. Seton (1886, p. 151) calls it a "common migrant along Red River", presumably on the authority of W. L. Hine of Winnipeg and/or C. W. Nash of Portage la Prairie. However, in the second installment of the same paper (1886, p. 329), he quotes R. H. Hunter as saying, "I have never seen the Knot along Red River, but have seen large flocks of the species west of Brandon." Cooke (1910) says "the species is unrecorded in the whole interior of Canada west of Hudson Bay", but Macoun and Macoun (1909) call it "a tolerably common migrant in Manitoba but rare farther west." Taverner (1943) records it as "migrating throughout the prairie interior." Possible reasons for these conflicting statements are discussed below.

More recent observations of this species in southern Manitoba are shown in Table 1 , and the locations of these observations are plotted in Figure 1.

For an uncommon species, the relatively large number of flocks compared to individual birds among these records is striking. Hunter's observations west of Brandon were of "large flocks"; Cartwright's Whitewater Lake observation is recorded in the plural ("Knots were observed") in such a way as to imply a flock or flocks; Gibson's observation at Lockport was of 21 birds; Mossop, Press, and Wallace saw a total of 12 at the Shoal Lakes; and Dr. Evans and I saw 15 at Delta. Only Mossop's ob- 


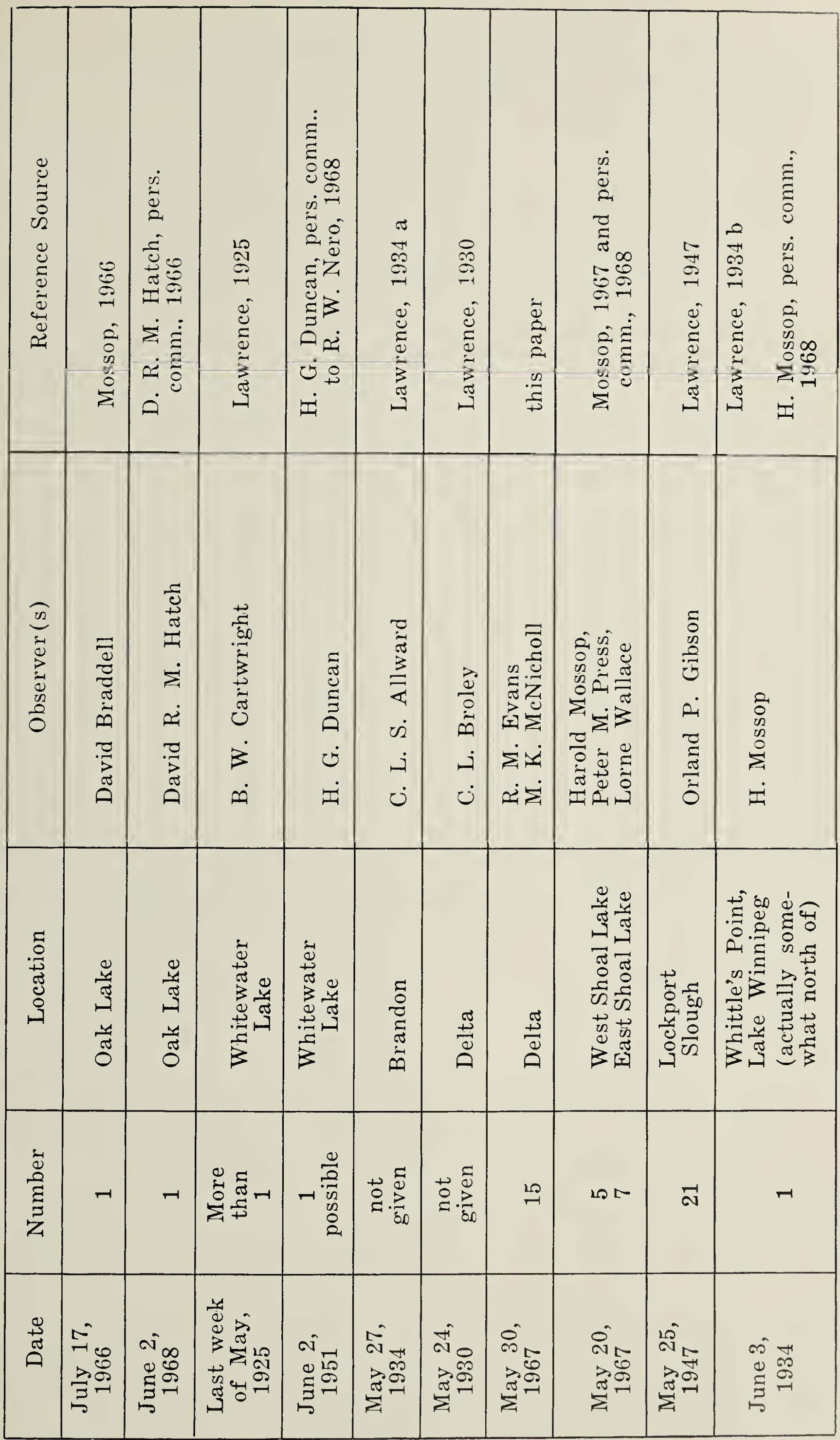


servation at Whittle's Point, Duncan's sighting at Whitewater Lake, and the Oak Lake observations of Braddell and of Hatch were definitely of single birds, although Broley's Delta observation and Allward's Brandon observation may have been of single birds also. Thus a high proportion of the southern Manitoba Knot observation is of flocks. This relatively high frequency of flocks may explain the earlier reports of its being common in migration in southern Manitoba or across the prairie, as writers with little information on this species might assess reports of large flocks as being indicative of general abundance, an impression which might also be given to observers of such flocks in the field.

The relatively high frequency of flocks need not be surprising. Aaron M. Bagg (1967) has shown how a combination of weather factors may have caused two great flights of the Lapwing (Vanellus vanellus) from Europe to North America. Similar factors could presumably cause the much smaller displacernent of small flocks of birds within North America. Such displacement of entire flocks might be particularly expected in the Knot, which is known to be highly gregarious. George H. Mackay is quoted by Bent (1927) as calling them "very gregarious", and Bent himself says they are "generally grouped in compact bunches and all moving along together; they are less likely to scatter over their feeding grounds than other waders."

The source of the Knots observed in Manitoba and the general pattern of Knot migration in western Canada cannot be determined in detail with our present knowledge. Records from this and adjacent areas, however, provide some clues.

The main migratory route of the Knot is along the eastern coast of North America (Bent, 1927; A.O.U., 1957 ), but it is a "tolerably common migrant throughout the Mississippi Valley east of the ninety-eighth meridian" (Cooke, 1910). At the Ontario Lakehead, the Knot has been recorded at least twice-once by Dr. A. E. Allin on May 25, 1955, and once by C. Garton on May 20, 1956 (H. Mossop, pers. comm.). Williams (1926) called it a "rare migrant" in the Red River Valley of North Dakota, but noted two fall records. In Saskatchewan, Mitchell (1924) recorded it as a hypothetical but probable spring migrant on the basis of one seen at Lake Johnstone (= Old Wives Lake) on May 13, and three on May 20, 1923. The species was substantiated for that province when Mitchell collected three of five seen at Imperial Beach, Last Mountain Lake on May

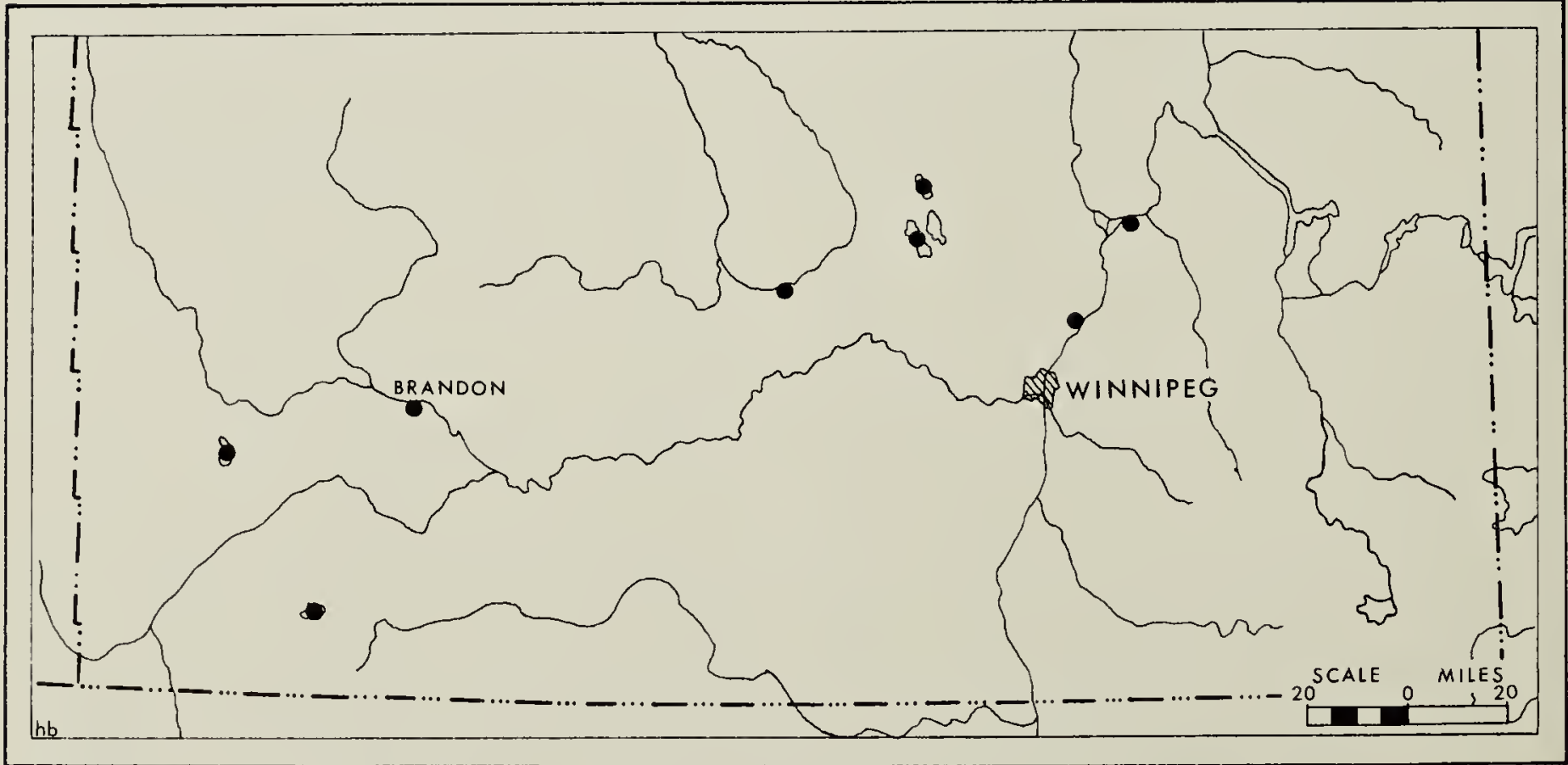

Fig. 1. Locations of Knot observations in southern Manitoba. 
Table 2. Knot records from southern Saskatchewan

\begin{tabular}{|c|c|c|c|}
\hline Date & Number & Location & Reference Source \\
\hline $\begin{array}{l}\text { May } 13,1923 \\
\text { May } 20,1923 \\
\end{array}$ & 1 & $\begin{array}{l}\text { Lake Johnstone } \\
(=\text { Old Wives } \\
\text { Lake })\end{array}$ & Mitchell, 1924 \\
\hline May 24,1931 & 1 & Old Wives Lake & Knight, 1967 \\
\hline May 27,1924 & $\begin{array}{c}5(3 \\
\text { collected })\end{array}$ & $\begin{array}{l}\text { Imperial Beach, } \\
\text { Last Mountain } \\
\text { Lake }\end{array}$ & $\begin{array}{l}\text { Mitchell, } 1925 \\
\text { Potter, } 1943\end{array}$ \\
\hline $\begin{array}{l}\text { May 24-25, } \\
\quad 1932\end{array}$ & $\begin{array}{c}2 \\
\text { (collected) }\end{array}$ & $\begin{array}{l}\text { Imperial Beach, } \\
\text { Last Mountain } \\
\text { Lake }\end{array}$ & Todd, 1947 \\
\hline May 25, 1964 & 2 & $\begin{array}{l}\text { south end of } \\
\text { Last Mountain } \\
\text { Lake (formerly } \\
\text { Valeport) }\end{array}$ & $\begin{array}{l}\text { Margaret Belcher, } \\
\text { pers. comm., } 1969\end{array}$ \\
\hline $\begin{array}{l}\text { May } 20,1934 \\
\text { May } 1957 \\
\text { May } 28,1958 \\
\text { May } 29-30, \\
\quad 1958 \\
\end{array}$ & $\begin{array}{c}2 \\
1 \\
3 \\
4 \text { (plus } \\
1 \text { on } 29 \text { th })\end{array}$ & Regina & Belcher, 1961 \\
\hline $\begin{array}{l}\text { May } 22,1966 \\
\text { May } 19-21, \\
\quad 1967 \\
\end{array}$ & $\begin{array}{l}2 \\
1\end{array}$ & Regina & $\begin{array}{l}\text { M. Belcher, } \\
\text { pers. comm., } 1969\end{array}$ \\
\hline $\begin{array}{r}\text { September } \\
24,1967 \\
\end{array}$ & 1 & Regina & Hatch, 1968a \\
\hline May 19,1968 & 100 & LaFleche & Hatch, 1968b \\
\hline May 22, 1963 & 4 & $\begin{array}{l}\text { Rutherford's } \\
\text { Slough, Moose } \\
\text { Jaw }\end{array}$ & Knight, 1967 \\
\hline $\begin{array}{l}\text { June } 6,1967 \\
\text { June } 9,1967 \\
\end{array}$ & $\begin{array}{c}5 \\
16 \\
\end{array}$ & Morse & $\begin{array}{l}\text { M. Belcher, } \\
\text { pers. comm., } 1969\end{array}$ \\
\hline May 21, 1959 & 1 & $\begin{array}{l}\text { Qu'Appelle } \\
\text { Valley (Fort } \\
\text { San) }\end{array}$ & $\begin{array}{l}\text { Storer, } 1959 \\
\text { Mosisop, } 1959\end{array}$ \\
\hline May 23, 1943 & about 12 & Melville & McKim, 1943 \\
\hline May 20,1962 & 1 & $\begin{array}{l}\text { Rice Lake, } \\
\text { Saskatoon }\end{array}$ & $\begin{array}{l}\text { Gollop, Roy, and } \\
\text { Folker, } 1963\end{array}$ \\
\hline May 20,1965 & 12 & $\begin{array}{l}\text { Porter Lake, } \\
\text { Saskatoon }\end{array}$ & $\begin{array}{l}\text { Gollop, Slimmon, } \\
\text { and Folker, } 1966\end{array}$ \\
\hline $\begin{array}{l}\text { May } 13,1966 \\
\text { May } 14,1966\end{array}$ & $\begin{array}{l}6 \\
4\end{array}$ & Saskatoon & Gollop, 1967 \\
\hline May 21,1967 & 5 & Saskatoon & Gollop, 1968 \\
\hline May 25,1968 & 3 & Saskatoon & Roy, 1968 \\
\hline May 18,1964 & 1 & Coteau Lake & Roy, 1968 \\
\hline
\end{tabular}


27, 1924 (Mitchell, 1925; Potter, 1943). Since that time there have been several other records from southern Saskatchewan as summarized in Table 2. In northwestern Saskatchewan the species is given as hypothetical for Lake Athabasca on the basis of one on August 20, 1920 and three on August 21, 1920 "seen, but not definitely identified" by Francis Harper at Fair Point, Lake Athabasca (Nero, 1963). This record was recently considered to be more definite by Harper (pers. comm. to R. W. Nero, September 17, 1963) on the basis of having heard the call which he recorded as "wahquoit". In the same correspondence Harper reports collecting a Knot on August 29, 1920, 10 miles N.N.E. of Sand Point, Alberta (on Lake Athabasca). W. Rowan regarded the Knot as a regular migrant in Alberta largely on the basis of about 200 seen on May 21, 1924 and over 150 on May 23, 1924 (Bent, op. cit.), and Salt and Wilk (1966) regard it as a scarce but regular migrant in Alberta during both spring and fall migrations. R. S. Palmer (in Stoudt, 1967, pp. 239240 ) records the interior flight east of the Rockies as "Alberta mainly."

Two features are noteworthy about these records. One is that all Manitoba records, with the possible exception of Braddell's Oak Lake obser-

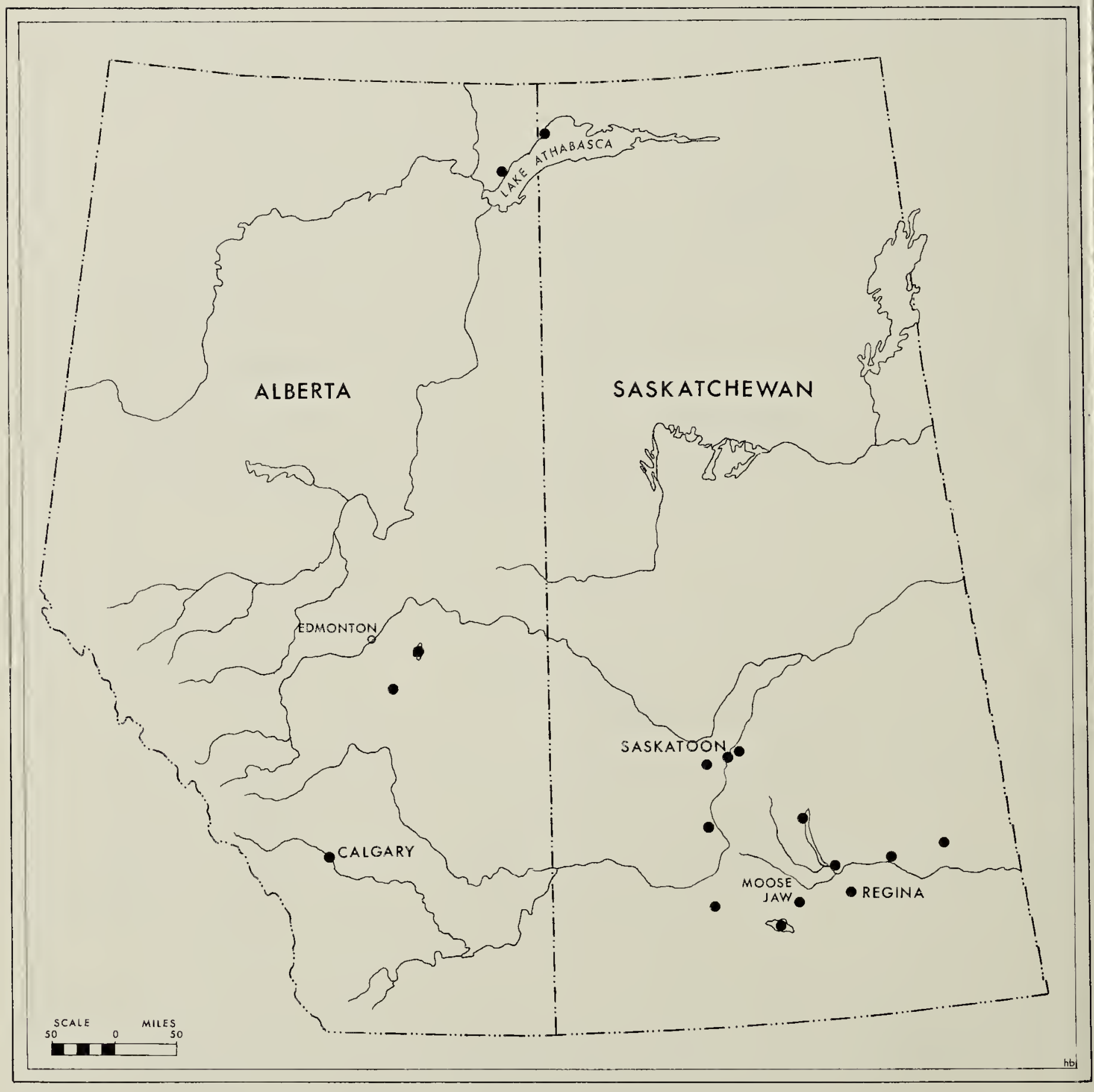

Fig. 2. Locations of Knot observations in Saskatchewan and Alberta. 
vation, and all of Saskatchewan's records except the Lake Athabasca records and one of the 1967 Regina records are of spring migrants, whereas in Alberta they are considered regular in both spring and fall. The other feature is that there is a considerable gap in locations of observations on the prairie (as shown in figure 2). Locations given for records in Alberta by Salt and Wilk (op. cit.) are in the western part of the province (Beaverhill Lake, Bittern Lake, Calgary area). On the other hand, the rest of the records are from Manitoba or east and central Saskatchewan, with no records from eastern Alberta or western Saskatchewan (except Lake Athabasca far to the north). Furthermore, in Alberta they are regular at Beaverhill and Bittern lakes where they occur "sometimes in large flocks" (Salt and Wilk, op. cit.), whereas they do not appear to be regular in southern Manitoba or Saskatchewan, and never have been noted in flocks of the size recorded for Alberta. These factors indicate that there may be two different pathways involved, one passing through western or central Alberta, the other east of Manitoba, and occasionally through eastern Saskatchewan and Manitoba.

In examining the distribution of these records it is interesting to note the differences in water availability in different portions of the prairie provinces. In Manitoba, south and west of the Precambrian Shield lies the broad, shallow Glacial Lake Agassiz Basin, of which Hochbaum (1967, p. 197) says, "Few regions of North America are so richly endowed with standing waters." Thus the region has plenty of water available most of the time. However, many of the water bodies in this area "are very shallow and disappear in very dry seasons" (Davis et al., 1926, p. 8). Since there has been essentially no change in topography since the latest glaciation (Davies et al. op. cit., pp. 149$160)$, this area has had plenty of water available for migrant waders for centuries, but this availability varies from one year to another and is more reliable in spring than in fall. Similarly, southeastern and south central Saskatchewan is largely an area of "very flat plains on ancient lake bottoms" (Fraser, et al. 1935), and thus with plenty of water available but susceptible to wet-drought periods. Southwestern Saskatchewan and southeastern Alberta, on the other hand, are largely made up of arid areas and areas of higher elevation with deeper lakes lacking enough shorelines and/or mudflats to be suitable for shorebirds (Fraser et al., 1935; Williams and Dyer, 1930). Farther west in Alberta there are lakes, such as Beaverhill Lake where the greatest number of Knots in Alberta have been observed, which are "large and shallow waters" (Bird and Bird, 1967) and thus have water and shoreline available to migrant waders in both spring and fall.

Cooke (1910), noting the absence of migrating Knots in the interior of Canada, suggrests that the birds in the interior (Mississippi Valley) flight must veer away from the ninetyeighth meridian and "fly north and a little east to Hudson Bay." As it would take only enough weather disturbance to keep them going north or deflect them slightly to the west to bring them to Manitoba or Saskatchewan, it seems most probable that our birds come from the Mississippi Valley flight. Since there is only a small Knot migration along coastal British Columbia, and there are no records for interior B.C. (Godfrey, op. cit.), it seems likely that the Alberta birds may represent a smaller contingent of the Mississippi Valley flight that veers west somewhat south of us, and proceeds along the eastern edge of the mountains, using this route to a lesser extent in the fall also. That this is possible is further borne out by the fact that although the main flight is farther east in the fall, there are several fall records from interior states (Bent, 1927).

Both the A.O.U. Check-list (1957) and Godfrey (1966) note that the fall migration is farther east than that 
of the spring. These conclusions appear to agree with the ManitobaSaskatchewan records, where the interior (Mississippi $\mathrm{Valley)}$ route appears to be used only in the spring. The Alberta birds, in contrast, stage regular flights in both seasons, although the fall flight appears to be smaller (Salt and Wilk, op. cit.). These records suggest, therefore, that the tendency for Knots to avoid the interior route in the fall applies primarily to the more eastern portion, including the Manitoba and eastern Saskatchewan birds, but to a lesser extent, if at all, to birds passing through Alberta. As noted above, this may be related to water availability.

Certainly our knowledge of the migratory pathways used by the Knot is at present scanty, and more information is needed before we can accurately map its "normal" and abnormal course. For the present, the status of the Knot in Manitoba appears to be: regular spring transient along Hudson Bay, and casual spring migrant in the south.

\section{Acknowledgments}

I would like to thank W. Harvey Beck for preparing the accompanying maps for this note; Miss Margaret Belcher, David R. M. Hatch, Harold Mossop, and Dr. Robert W. Nero for information on some of the records; Dr. Roger M. Evans and Dr. Robert W. Nero for critically reading the manuscript; and particularly Herbert W. R. Copland for his work in locating the A. G. Lawrence references to the Knot. My work at the field station was financed by a National Research Council of Canada grant.

\section{LITERATURE CITED}

A.O.U. Committee. 1957. Check-list of North American birds. Fifth ed. Baltimore. 691 pp.

Bagg, A. M. 1967. Factors affecting the occurrence of the Eurasian Lapwing in eastern North America. Living Bird sixth annual. pp. 87-121.

Belcher, M. 1961. Birds of Regina. Spec. Publ. No. 3. Sask. Nat. Hist. Soc., Regina. $75 \mathrm{pp}$. Bent, A. C. 1927 (Dover ed., 1962). Life histories of North American shorebirds. Part I. U.S. Nat. Mus. Bull. 142. 359 pp.

Bird, C. D. and R. D. Bird. 1967. The Aspen Parkland. Chapter 7, pp. 135-149 in Alberta, a natural history (W. G. Hardy, editor).
Cooke, W. W. 1910. Distrioution and migration of North American shorebirds. U.S. Dept. Agr. Biol. Surv. Bull. No. 35. 100 pp.

Davies, J. F., B. B. Bannatyne, G. S. Barry, and H. R. McCabe. 1962. Geology and mineral resources of Manitoba. Man. Dept. of Mines and Nat. Res. 190 pp.

Fraser, F. J., F. H. McLearn, L. S. Russell, P. S. Warren, and R. T. D. Wickenden. 1935. Geology of southern Saskatchewan. Mem. 176. Can. Dept. of Mines, Ottawa. 137 pp.

Godfrey, W. E. 1966. The birds of Canada. Nat. Mus. Can. Bull. No. 203, Biol. Series No. 73. Ottawa. $428 \mathrm{pp}$.

Gollop, J. B. 1967. 1966 review of Saskatoon bird observations. Blue Jay $25: 15-20$.

Gollop, J. B. 1968. 1967 review of Saskatoon bird observations. Blue Jay $26: 126-130$.

Gollop, J. B., J. F. Roy and R. V. Folker. 1963. Some 1962 bird records from the Saskatoon district. Blue Jay $21: 12-13$.

Gollop, J. B., J. A. Slimmon and R. V. Folker. 1966. Some 1965 bird records for the Saskatoon district. Blue Jay $24: 76-78$.

Hatch, D. R. M. (editor), 1968a. Fall migration. August 16 to November 30, 1967. Northern Great Plains Region. Audubon Field Notes $22: 54-57$.

Hatch, D. R. M. (editor). 1968b. Spring migration, April 1 to May 31, 1968. Northern Great Plains Region. Audubon Field Notes $22: 544-547$

Hochbaum, H. A. 1967. Contemporary drainage within true prairie of the Glacial Lake Agassiz Basin. pp. 197-204. in Life, Land and Water, (W. J. Mayer-Oakes, editor).

Knight, L. M. 1967. Birds of the Moose Jaw area. Moose Jaw Nat. Hist Soc. mimeo. pp.

Lawrence, A. G. 1925. A new species for Manitoba. "Chickadee Notes", No. 220. Winnipeg Free Press June 12, 1925.

Lawrence, A. G. 1930. Migration reports. "Chickadee Notes", No. 479. Winnipeg Free Press May 30, 1930.

Lawrence, A. G. 1934a. Migration reports. "Chickadee Notes", No. 688. Winnipeg Free Press June 1, 1934.

Lawrence, A. G. 1934 b. Miscellaneous notes. "Chickadee Notes", No. 690. Winnipeg Free Press. June 15, 1934.

Lawrence, A. G. 1947. Migration almost at an end. "Chickadee Notes", No. 1359. Winnipeg Free Press. June 6, 1947.

Macoun, J. and J. M. Macoun. 1909. Catalogue of Canadian birds. Can. Dept. of Mines, Ottawa. viii plus 161 pp.

McKim, L. T. 1943. The luck of a naturalist. Blue Jay $1(4): 28$.

Mitchell, H. H. 1924. Birds of Saskatchewan. Can. Field Nat. $38: 101-118$.

Mitchell, H. H. 1925. Some more notes on Saskatchewan birds. Condor $27: 94-96$.

Mossop, H. 1959. Migration reports "Chickadee Notes", No. 229, Winnipeg Free Press, June 7, 1959.

Mossop, H. 1966. A rare bird is the Knot. "Chickadee Notes", No. 612. Winnipeg Free Press. October 8, 1966.

Mossop, H. 1967. Migration reports. "Chickadee Notes", No. 646. Winnipeg Free Press. June 3, 1967.

Nero, R. W. 1963. Birds of the Lake Athabasca region, Saskatchewan. Spec. Publ. No. 5. Sask. Nat. Hist. Soc., Regina. $143 \mathrm{pp}$.

Nero, R. W. and H. Hosford. 1967. Field check-list of Manitoba birds. 
eterson, R. T. 1947. A field guide to the birds (second revised ed.). Houghton Mifflin Co., Boston. 290 pp.

otter, L. B. 1943. Saskatchewan bird records made since the publication of Mitchell's catalogue of Saskatchewan birds in 1924. Blue Jay $1(3): 25$.

Roy, J. F. 1964. An introduction to the birds of the Elbow. Sask. Nat. Hist. Soc. Mimeo. $33 \mathrm{pp}$.

Loy, J. F. 1968. Annual May Day bird count, Saskatoon. Blue Jay $26: 141-143$.

alt, W. R. and A. L. Wilk. 1966. The birds of Alberta. Second (revised) ed. Dept. of industry and develoment. Alta. govt. $511 \mathrm{pp}$. eton, E. E. T. 1886. The birds of western Manitoba. Auk. $3: 145-156 ; 320-329$.
Storer, R. W. 1959. Spring in the Qu'Appelle Valley. Blue Jay 17:90.

Stoudt, G. D. (editor). 1967. The shorebirds of North America. The Viking Press, New York, 270 pp.

Taverner, P. A. 1934. Birds of Canada. Can. Dept. of Mines Bull. No. $72.445 \mathrm{pp}$.

Todd, W. E. C. 1947. Notes on the birds of southern Saskatchewan. Ann. Carnegie Mus. $30: 383-421$.

Williams, H. V. 1926. Birds of the Red River Valley of northeastern North Dakota. Wilson Bull. $38: 17-33 ; 91-110$.

Williams, M. Y. and W. S. Dyer. 1930. Geology of southern Alberta and southwestern Saskatchewan. Mem. 163. Dept. of Mines, Ottawa. 160 pp.

\title{
FURTHER RECORDS OF THE VARIED THRUSH AT ROSETOWN, SASKATCHEWAN
}

\author{
by Wayne Renaud, Rosetown
}

In the September 1968 Blue Jay 26:122-3) I reported seeing a Varied Thrush (Ixoreus naevius) at Roseown on October 9 and 10, 1967. Since hen, we have had two records for his area which I should like to eport.

On May 6, 1968 a Varied Thrush vas positively identified at Valley lentre (18 miles north and seven niles east of Rosetown) by Mrs. H. Renaud when it came within yards $f$ the picture window.

On September 22, 1968 another ndividual was sighted and photoraphed at the same location. Because was evidently suffering from a ving injury it was unusually tame. It as observed from about $4: 00$ to $4: 30$ m. when it remained in the same roup of trees; then it flew off and as not seen again until 6:00 p.m. when it was sighted in the neighour's trees. It was apparently beoming very weak because it was ushed from the ground twice and nly flew a few yards before alightng once more. Attempts to capture proved fruitless.

On the morning of September 23 it vas caught by a cat, but the wings, ail and parts of the back and breast vere salvaged, and I sent these to the
Editor of the Blue Jay, establishing positively the occurrence of the bird in the Rosetown area.

These sightings indicate that the Varied Thrush may not be as rare in Saskatchewan as once thought.

[Editor's Note: It is also of interest that the Varied Thrush reappeared in Regina in the fall of 1968. A single bird of this species was seen at the McKay's bird bath on Angus Street, near the Legislative Buildings, on October 9, 1968. It was observed on that date by Mr. and Mrs. J. F. McKay, who showed it the following day to Dr. George Ledingham and myself. A second observation of a Varied Thrush in a different location was made on November 9 by Ken Johnson at 1522 Athol Street, who called Frank Brazier to confirm his identification. Then on November 14, a Varied Thrush appeared on the east side of the city, on Winnipeg Street, where it was first reported by Mrs. Dorothy Tegart. It was seen again in the backyard on a number of occasions up to November 28, by Mrs. Tegart and myself. It was never established whether it was the same individual that was observed in the three different locations.-Margaret Belcher.] 